\title{
AUTHENTIC LEADERSHIP BEHAVIOR IN MADRASAH ALIYAH IN TASIKMALAYA REGENCY
}

\section{AAN KOMARIAH}

Department of Education Administration, Education University of Indonesia (UPI) Jl. Dr. Setiabudi No. 229, West Java

Email: aan_komariah@upi.edu

\begin{abstract}
This research aims to know the relation between Spiritual Intelligence and Leader Personality with Authentic Leadership Behaviour. This research uses quantitative research approach with type of correlation approach. This research is done at 77 headmasters of Mardasah Aliyah in Tasikmalaya Regency. The samples are done by using simple random sampling technique. The research result shows that there is positive between Spiritual Intelligence and Leader Personality with Authentic Leadership Behaviour. The positive correlation coefficient shows that if the Spiritual Intelligence increases, so the authentic leadership behaviour will also increase. Also with the increasing of Leader Personality will increase the Authentic Leadership behaviour. The Spiritual Intelligence and Leader Personality all together affect significantly to the Authentic Leadership Behaviour.
\end{abstract}

Keywords: Leader Personality, Organizational Commitment, Authentic Leadership

\section{ABSTRAK}

Penelitian ini bertujuan untuk mengetahui bubungan anatara kemampuan spiritual dan kepribadian seorang pemimpin melalui perilaku kepemimpinan otentik. Penelitian ini menggunakan pendekatan kuantitatif dengan tipe korelasi. Objek penelitian ini adalah 77 kepala sekolah madrasah Aliyah di kabupaten Tasikmalaya. Sampelnya menggunakan teknik random sampling sederhana. Hasil dari penelitian ini menunjuk.kan bahwa ada korelasi positif antara kemampuan spiritual dan kepribadian pemimpin melalui perilaku kepemimpinan otentik. Koefisien korelasi positif ini menunjukkan bahwa jika kemampuan spiritual meningkat maka perilaku kepemimpinan otentik pun akan meningkat. Dan juga akan berpengaruh pada pribadi yang berkepemimpinan. Kemampuan spiritual dan pribadi pemimpin secara keseluruban sangat berpengaruh terhadap perilaku kepemimpinan otentik.

Kata Kunci: Kepribadian Pemimpin, Komitmen Organisasi, Kepemimpinan Otentik.

\section{INTRODUCTION}

Among many discussions about leadership in Indonesia, this nation requires a person who firmly with his leadership integrity as well as is able to serve the community professionally. It takes a good heart leader that is willing to sacrifice and willing to work optimally in order to bring his followers out of the crisis facing. George (2014, p. 32) states that we need authentic leaders. 
My hope is that you will be inspired to become an authentic leader, committed to making the world better for all its citizens, and leading with your heart as well as your head (George, 2014, p. 32). In addition to a good personality leadership, it is also required a leader with a qualified spiritual intelligence which can affect leader's authentic behaviour in conducting the leadership mandate.

Authentic leader is a leader with very high integrity in building organizational commitment. Leaders who have the determination to the objectives to be achieved departing from the organization's core values he believes in. Authentic leaders are leaders who promote moral and characterbased leader (George, 2014, p. 28). By promoting moral and character-based leader, the authentic leader is a leader with a good personality as well as a good spiritual intelligence. Authentic leaders have a sincere desire to serve those led, by the leadership, all of the staffs who are in his charge, no one felt "burn-out", because he empowers all staffs according to their capacity to contribute. Authentic leaders lead the staff with a good heart, a sincere soul and qualified mind. (George, 2014, p. 35), this shows that he must be someone with a good personality.

Authentic leaders are not born in the middle of the road; many people are awarded as leaders but they do not continue to develop their leadership to fully pay attention to the progress of the people that they lead. The authentic leaders lead with purpose, understanding, and values. They build relationships with people and they believe in their leadership because of the obvious consistency between what is said and their self-discipline (George, 2014, p. 35). It becomes very suitable to be applied to the institution that confirms its existence as a learning organization rooted in religious-based spiritual values that is madrasah.

Madrasah is expected to be an educational institution that is able to lead learners in the realm of a more comprehensive, covering intellectual, moral, spiritual and skills aspects in an integrated way. Therefore, madrasah should be able to integrate the religious maturity and expertise of modern science to students by presenting itself as a representation institution of Islamic teachings which are great, beautiful, and perfect. However, in reality, the madrasah is still struggling to get the idealism into reality. The Islamic ideal concepts, such as an atmosphere of togetherness, hard work, discipline, optimism to steer clear of desperate, easily to give up, always keeps both inner and outer cleanness, and so as wishful thinking. It is not impossible to realize it but it requires a determined person to make it happen, he is the leader of the madrasah.

Learning the authentic leadership concept cannot be separated from some figures who are hard-working in researches in this field. Starting from 
convergence of theoretical stream (Avolio, Gardner, Walumbwa, \& Mei, 2004; Luthans \& Avolio, 2003), positive organizational behavior (Luthans, 2002a; 2002b), authenticity (Kernis, 2003), and self-determination (Deci \& Ryan, 2000). Darvish and Rezaei (2011) mention four authentic leadership aspects, namely self awareness, self-regulation, relational transparency, balanced processing (Darvish \& Rezaei, 2011, p. 423 ). George, (2014, p. 41) shows the authentic leadership dimension, namely: 1) Understanding their purpose, 2) Practicing solid values, 3) Leading with heart, 4) Establishing connected relationships, 5) Demonstrating selfdiscipline. The essential value of authentic leadership is placing the relationshiop with its followers as its leadership soul caller (Gardner, Avolio, Luthans, May, \& Walumbwa, 2005; Avolio \& Gardner, 2005). Komariah (2012, p. 196), uses six authentica leadership pillars namely: Self-awareness, Purpose/Vision, Value/Etica/moral, Relationship, Behavior/self-discipline, dan Transparancy.

The experts have created authentic leadership theoretical models focusing on authentic component, self-realization, and eudemonic well-being (self-realization) (real happiness - soul prosperity) (Kernis, 2003; Ilies et al, 2005, Gardner etal, 2005a.; Walumbwa et al., 2008). Out of all which have been explained by the experts above, the basic components from the authentic leadership are self-awareness, unbiased processing, Authentic behavior/action, and relational authenticity (Kernis, 2003; Goldman \& Kernis, 2002), Ilies et al. (2005). (Opatokun, Hasim, \& Syed Hassan, 2013).

Table 1: The Self in Selected Models of Authentic Leadership

\begin{tabular}{|c|c|c|c|c|c|}
\hline Facets of self & $\begin{array}{l}\text { Gardner et al. } \\
2005\end{array}$ & $\begin{array}{c}\text { Avolio et al. } \\
2004\end{array}$ & $\begin{array}{c}\text { Ilies et al. } \\
2005\end{array}$ & $\begin{array}{c}\text { Klenke } \\
2004\end{array}$ & $\begin{array}{c}\text { Komariah } \\
2012\end{array}$ \\
\hline Self-awareness & $\mathbf{\square}$ & & & & $\mathbf{\square}$ \\
\hline Self-knowledge & & & & & \\
\hline Self-regulation & a & & & & 口 \\
\hline Self-esteem & & & a & & \\
\hline Self-efficacy & & & a & a & \\
\hline Self-motivation & & & & [ & - \\
\hline $\begin{array}{l}\text { Self-identity (personal } \\
\text { identification) }\end{array}$ & & E & & & \\
\hline Self-development & & & [ & & - \\
\hline Self-transcendence & & & & [ & \\
\hline Self-sacrifice & & & & - & \\
\hline
\end{tabular}

Source is adapted from (Klenke, 2007), Komariah (2012)

The madrasah leadership requires an authentic leader who must be honest to himself (May, Chan, Hodges, \& Avolio, 2003). Meaning, it is possessed the harmony between the behaviour and trust. To be the authentic leader, George (2003) shows a statement, "To become authentic, each of us has to develop our own leadership style, consistent with our personality and character". That to be authentic, each of us must develop our own leadership 
style, according to the personality and our character. If we are not consistent with what are from ourselves, how it can be possible to be a true leader. The authentic leaders are consistent and show the unity of mind-attitude-action. Developing the authentic leadership in an organization teaching the value system and in the turbulence situation is very prominent (Cooper et al, 2005, p. 476). The spirituality and spiritual identity are the core of authentic leadership (Klenke, 2007, p. 68).

The authentic leadership firmly stands on the personality and spirituality. The work spirituality is generally associated with religiosity, when spirituality is added to the context of the work, then it cannot be separated from religion. Delbecq (2005, p. 247) explains, "In managers" opinions, organizational leaders do not have to distinguish between spirituality and religion". Confirmed by Ayrancy (2011, p. 137), the work spirituality does not only talk about the organizational values, but also includes the use of prayer, the use of religious symbols, rituals such as (meditation and yoga) to cope with the work environment. Similar opinion is expressed by Sutcliffe and Bowman (2000) who insist on using religion combination and psychology in the workplace. However, there are some studies choosing other factors to be used as a parameter and excluding the religion as a part of spirituality.

Shaw (1999, p. 68) defines the work spirituality as having a positive mood in the work context, while Ayrancy (2011, p.137) have focused their research on the spiritual values of the people in workplace. Meanwhile, Mohamed, Wisnieski, Askar and Syed (2004, p. 107) assert that spirituality is part of the personal personality in the context of the work. Ashmos and Duchon (2000, p. 135) like the separation between spirituality and religiosity in the workplace. (Ayranci \& Semercioz, 2011, p. 137). Zohar and Marshall (2005, p.xix) also distinguish the spiritual terms with religious or other organized belief system. Zohar and Marshall take a spiritual term derived from the Latin word that is spiritus, meaning something that gives life or vitality to a system.

Zohar and Mashall $(2000$, p. 4) states that the spiritual intelligence is the intelligence to deal with the problem of meaning or value, namely the intelligence to put the behaviour and our lives in the context of a broader and rich meaning, the intelligence to assess more meaningful person's actions or way of life than others; The spiritual quotient is the highest spiritual intelligence to be possessed by a leader in implementing their mandate. The spiritual quotient (SQ) allows a leader to think in a creative, far ahead resourceful and be able to make even change the rules. Furthermore, Zohar and Marshall argue that there are people's characteristics who have a high SQ, namely: a. Self-awareness, b. Spontaneity, c. Guided by the vision and values, d. Holism (awareness to the system or connectivity), e. Concern, f. 
Celebrating diversity, g. Independence of the environment (field independence), h. A tendency to ask the fundamental question, i. The ability to reframe, j. Utilizing adversity positively, k. Humble, and l. A sense of calling.

A headmaster as a top leader plays a central role as the driving agent, motivator and facilitator for the growth of participation, motivation and performance of all madrasah's stakeholders in an effort to improve the madrasah's quality; Especially to transmit the spirit of hard work and quality which starts from himself as a hard worker who has full awareness to lead with full responsibility. Making madrasah as the most appropriate place to learn for growing and rooting the spiritual values in life requires the authentic leaders who have reliable spiritual intelligence and personality.

Personality becomes an important variable in realizing the authentic leadership behaviour. The personality is an individual characteristic inherent in a person and is stable over time. The personality concept is explained by the personality theory which is a branch of psychology. This concept reflects a paradigm shift in the field of psychology such as personality characteristics and individual differences, including work behaviour (McCrae \& Costa, 1992, p. 175). The personality characteristics that are often used in various studies related to the one's work behaviour is The Big Five Personality, which divides the personality characteristics into five dimensions, namely Openness to experience, Conscientiousness, Extraversion, Agreeableness, and Neuroticism (OCEAN).

The leaders with "O" Personality is a personality characterized by imaginative, ingenious, fondness of variety, curiosity, creativity, innovative, having a free and original thinking, and artistic characteristics; vice versa when the openness to experience characteristic is low or closed to experience, it tends to be a person who is not innovative, fondness of something routine, practical, and tending to be closed. McAdams \& Pals (2006) explain that a person with "O" personality characteristic has a high intellectual so he or she has innovation and ingenuity in solving problems. The leader with authentic behaviour has a personality characteristic of openness to experience which has high intelligence and creativity so that he or she can carry out the effective leadership mandate.

The leaders with conscientiousness personality characteristic or "C" personality is the figure of hardworking, disciplined, reliable, organized, meticulous and detailed, and tending to be diligent (Rustiarini, 2013, p. 130). A person with this personality characteristic has a strong motivation to achieve success (Zimmerman, 2008, p. 340), and has a task-oriented behaviour (Ashton \& Lee, 2007, 65), McGregor (1954, p. 96) calls this as the $\mathrm{Y}$ theory. Instead a careless, lazy, disorganized, and unreliable person, 
McGregor (1954, p. 96) refers it as an X human or X Theory; he or she is a leader with a low level of conscientiousness personality. Leaders with hardworking personality characteristic has great potential for the growth of authentic leadership by taking into account the authentic leadership characteristics, that is self-discipline.

An extraversion personality or the "E" personality characteristic highly tends to be talkative, energetic, enthusiastic, assertive and sure, friendly, and sociable (Rustiarini, 2013, p. 130). Leaders with extraversion characteristic shows a tendency to spend a lot of time in social situations and expresses positive emotions (Judge et al., 2002, p. 766), he or she is a jaunty and creator of the atmosphere. Meanwhile, leaders with low extraversion personality characteristic has quiet, shy, difficult to get along, and not overly excited personalities. Barrick et al. (1993, p. 270) finds that this personality characteristic has a strong influence on the individual performance. Leaders with extraversion personality are someone who can potentially take into account the authenticity characteristics from the relationship. (Komariah, 2012, p. 197).

Leaders with a personality characteristic of agreeableness or high "A" personality can work together in a team working, be trustworthy, caring, kind, helpful, unselfish, forgiving, and does not like to quarrel with others. In contrast, individuals with low agreeableness like find others' fault, fondness of disagreement, indifferent, disrespectful, and selfish (Rustiarini, 2013, p. 130).

Leaders with a personality characteristic of neoriticism or "N" personality is negative as indicated by such characteristics like often feeling depressed, full of tension and anxiety, easily gloomy and sad, easily agitated and depressed, and tending to have unstable emotions. Leaders should have low "N" personality with emotional stability, good ability to handle stress, not easily upset, quiet despite being in a stressful situation, and not easily stressed (Rustiarini, 2013, p. 130).

Referring to the descriptions above, the questions posed in this study are: 1) whether the spiritual intelligence affects on the authentic leadership behaviour; 2) whether the leader's personality affects on the authentic leadership behaviour; and 3) whether the spiritual intelligence and leaders' personality affect on the authentic leadership behaviour? Thus, this study aims to demonstrate empirically the influence of spiritual intelligence and leaders' personality independently to the authentic leadership behaviour. The relationship pattern between the spiritual intelligence and personality variables on the authentic leadership behaviour in this study is shown in Figure 1. 


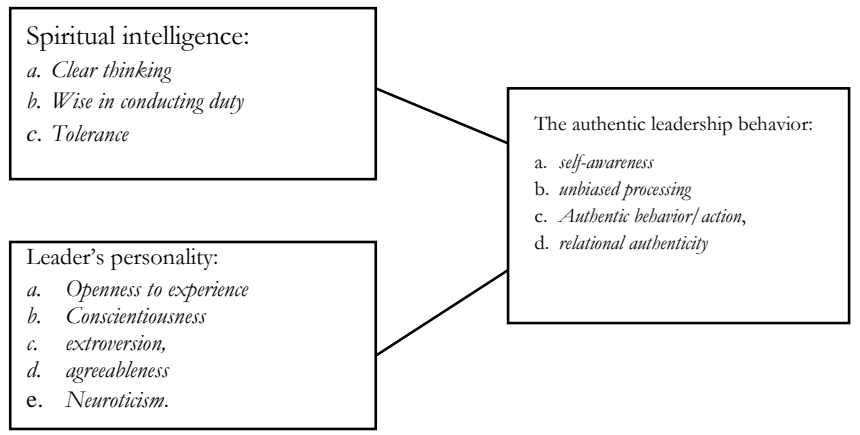

Figure 1.The Conceptual Framework of Spiritual Intelligence and Leaders' Personality with Authentic Leadership

This study is a field study using quantitative methods, using questionnaires of a five scale-model as a means of collecting data on 77 Headmasters taken randomly. The statistical calculation for data analysis is performed by using multiple regression analysis to determine the spiritual intelligence and leader's personality to the authentic leadership behaviour with SPSS.

The spiritual intelligence is measured by the instrument developed by Amram and Dryer's (2008, p. 20), that is integrated spiritual intelligence scale (ISIS), Zohar and Marshall (2007), and Puluhulawa (2013, p. 142), by using three indicators, namely: 1) to think clearly (fitrah), 2) wise in conducting duty, and 3) tolerance. The variable of the leader's personality characteristic is measured using The Big Five Personality adapted from McCrae \& Costa (1992, p. 200) consisting of five dimensions, namely openness, conscientiousness, extroversion, agreeableness, and neuroticism. While the authentic leadership behaviour is measured based on the item model adaptation used by Walumbwa et al, (2008, p. 102) and Komariah (2012, p.169) consisting of (self-awareness), unbiased processing, Authentic behavior/action, and relational authenticity.

The data analysis technique with multiple linear regressions to meet the requirements has been done by testing the validity and reliability of the instrument, and has been free from problems of normality, multi-co linearity, and heteroscedasticity (Sugiyono, 2004, p. 32).

\section{FINDINGS AND ANALYSIS}

In the descriptive analysis, it will be known the aspect distribution of the spiritual intelligence, personality and authentic leadership variables overall which are obtained from the respondents' answers by questionnaires. The descriptive analysis results of the study variables are shown in Table 1 
presenting that for the spiritual intelligence variable measurement, the highest score of the participants is the nature of thinking clearly and the lowest one is the tolerance. Meaning, generally the headmasters as the study participants in this study have the spiritual intelligence which is shown by the attitude of persevering prayer, love, honest, grateful, fair, wise in conducting duty, humble, forgiving, patient, counsellor, gentle, and a sense of responsibility. But for the tolerant attitude aspect, it needs to be improved in terms of respect the beliefs of others, open, willing to serve, not hurt, and peace.

For the measurement of leader's personality characteristic, the highest score of the participants is the agreeableness and the lowest one is the neuroticism. Meaning, generally the headmasters as the participants of this study have friendly, gentle heart, trust in others, generous characteristics. The low neuroticism aspect shows that the headmasters has stable emotional, can handle stress well, are not easily upset, are quiet despite being in a stressful situation, and are not easily stressed.

For the measurement of the authentic Leadership variable, the highest score of the participants is the Self Awareness and the lowest aspect is Relational authenticity. Meaning, generally the headmasters as the participants of this study show leadership with confidence, hope, optimism, and tenacious. But for Relational authenticity aspects, it needs to be improved in terms of listening, interpreting, and processing negative and positive information objectively before making the decision.

Table 2

Variables of Spiritual Intelligence, Leader's Personality Characteristics and Authentic Leadership of the Madrasah's Headmasters

\begin{tabular}{|l|c|c|c|l|}
\hline \multicolumn{1}{|c|}{ Dimension } & Average & SD & Percentage & Category \\
\hline Thinking clearly (Fitrah) & 3,816 & 0,757 & 76,32 & High \\
\hline Wise in conducting duty & 3,813 & 0,734 & 76,25 & High \\
\hline Tolerant & 3,644 & 0,725 & 72,89 & High \\
\hline Openness & 4,216 & 0,719 & 84,31 & Very High \\
\hline Conscientiousness & 3,778 & 0,723 & 75,55 & High \\
\hline Extroversion & 3,628 & 0,769 & 72,56 & High \\
\hline Agreeableness & 3,737 & 0,707 & 74,75 & High \\
\hline Neuroticism & 1,994 & 0,736 & 19,89 & Low \\
\hline Self-Awareness & 4,268 & 0,782 & 85,37 & Very high \\
\hline Unbiased processing & 3,919 & 0,762 & 78,38 & High \\
\hline Authentic behavior/action & 3,824 & 0,805 & 76,49 & High \\
\hline Relational authenticity & 3,729 & 0,844 & 74,58 & High \\
\hline
\end{tabular}

Source: Processing Data, 2015 
Based on the regression calculation results, it is known simultaneously that there is variance of 0.6420 or $64.20 \%$ in the authentic leadership and based on testing results that the value $\mathrm{F}_{\text {count }}$ is 105.08 with $\mathrm{F}_{\text {table }}$ of 2.25 so $\mathrm{F}_{\text {count }}>\mathrm{F}_{\text {table }}(105.08 .>$. 2 , 25); it can be said that the authentic leadership is affected all together and significantly by the spiritual intelligence and Leader's Personality Characteristics of $64.20 \%$., so that these give strong enough total effect to the Authentic Leadership. Also, there is $35.80 \%$ of other variables' effects which cannot be explained.

The multiple regression analysis by inputting spiritual intelligence and leader's personality characteristic variables produce a regression equation of $\mathrm{Y}=19.778+0,1871 \mathrm{X} 1+0.1794 \mathrm{X} 2$. With ei $=35.80$ and $\mathrm{R}^{2}=0.6420$. The hypothesis Testing based on the calculation results is known that $64 \%$ of authentic leadership is described by the spiritual intelligence and leader's personality characteristic $(\mathrm{R}=0642)$. This shows a jointly relationship between both variables of the spiritual intelligence and the leader's personality characteristic to the authentic leadership variable. A Constant of 19.778 indicates that if the spiritual intelligence (X1) and the leader's personality (X2) values are zero, then authentic leadership has a value of 19 778. The regression equation means that every increase of 1 point or $1 \%$ of spiritual intelligence and leader's personality characteristic variables will increase the authentic leadership of 0.1871 and 01794 . To test whether the Spiritual intelligence and the leader's personality characteristic affect on the authentic leadership variable partially, then the t test is conducted. Based on the calculation results, the values of all $p$ variables are less than 0.05 , which means that the spiritual intelligence and the leader's personality characteristic all together and significantly affect on the authentic leadership. This implies that if the headmasters have high spiritual intelligence and high leader's personality characteristic, so the headmasters' authentic leadership will be better.

The study provides an overview that Spiritual Intelligence of the Headmasters affects positively and significantly on the authentic leadership. That the authentic leadership has value / moral / spirit-based pillar which is believed to be the leadership work foundation along with many less pleasing behaviours to the public as in the value-based leadership study (Majer 2006; Vadim Kotelnikov, 2006; Kuczmarski, 1995 ) and moral-based leadership (Ryan, 2008, p. 13), with the elements; 1) Morality, 2) Commitment, 3) Productivity. In the context of the Islamic spiritual, Nashori and Mucharam (2002, p. 7) state that the Islamic religiosity consists of five aspects: (1) ideological (aspects of belief); (2) ritualistic (aspect of worship); (3) experiential (aspect goodness); (4) intellectual (the aspect of science); and (5) consequential 
(aspects of religious impact). These five aspects should be integrated in a madrassa's leader.

The effect of spiritual intelligence to the authentic leadership can also be seen on the ability of a leader in his persistence in carrying out his belief including the organizational vision; Nggermanto (2002, p. 98) says that a person who has a high SQ is a person who has strong principles and vision, is able to interpret each side of life and be able to manage and persist in trouble and pain. Therefore, the spiritual intelligence can significantly improve the headmasters' authentic leadership skill, so the spiritual intelligence is absolutely necessary in order that the headmaster can achieve success in carrying out the leadership mandate. Munir (2003, p. 12) states that spiritual intelligence teaches people to express and gives meaning for every action, so if you want to show a good performance, so it is needed the spiritual intelligence. Likewise Agustian (2001, p. 15) suggests that the spiritual intelligence as the ability to give meaning to worship for any behaviours and activities, by fitrah steps and thoughts, leading to wholly (Hanif) man and having the mindset of tawhid (integrative) and also having principle of "because God". This confirms the importance of spiritual intelligence in the work especially for the headmaster who has a high mission of Islamic spirituality.

The spiritual intelligence clearly has significant effect on the authentic leadership because the essence of spiritual intelligence is an aspect as the basis for the authentic leadership, at least it is evidenced by its self-awareness in the spiritual intelligence as the main pillar of the authentic leadership. Zohar and Ian Marshall (2007, p. 42), suggests the eight aspects of spiritual intelligence including: (1) the self-capacity to be flexible, such as active and adaptive spontaneously, (2) the high level of self-awareness, (3) self-capacity to deal with and take advantage of suffering, (4) the quality of life that is inspired by the vision and values, (5) aversion to cause unnecessary harm, (6) having a holistic perspective, with having the tendency to see the connection between all different things, (7) having a real tendency to ask and seek fundamental answers, and (8) having the ease to work against tradition (convention). The research results by Noble (2001, p. 74) state that high spiritual intelligence can contribute to mental health and logical behaviour, and this is very important for authentic leadership behaviour. Another dimension as the unique characteristic of the authentic leadership is the internalization of moral perspective dimension as the main study of spiritual intelligence. Avolio et al., (2005, p. 315) state that self-regulation (internalization of moral perspective) is the authentic leader characteristic who always acts and behaves according to the values he believes in by the action on the field. 
The research result of Personality characteristic of Madrasah Headmasters positively and significantly affects on the authentic leadership using five dimensions namely openness to experience, conscientiousness, extraversion, agreeableness, and neuroticism. The research result by Duehr (2005, p. 751) states that the big five personality and transformational leadership will result in job performance, while Leung et al, $(2004$, p. 62) shows that the effective leaders are considered to show the characteristics related to extraversion (open), conscientiousness (consciousness, meticulous, discipline), agreeableness (friendly), extraversion, emotional stability/neuroticism, and openness to experience (Innovative and creative). That to realize the authentic leadership, the headmasters must have personality characteristics as the leaders in terms of high ownership in the four personality characteristics namely openness to experience, conscientiousness, extraversion, agreeableness, and must be low in terms of the personality characteristic of neuroticism.

It is important for the headmasters to know the nature of their personality to be a self-evaluation tool for the implementation of authentic leadership. The Big Five Personality becomes reinforcement for the realization of authentic leadership by the extraversion which is expressed by the warmth, positive emotion, assertiveness, and gregariousness (friendship) of headmasters in taking decisions and the leadership attitudes. Openness to experience is a person required to become an authentic leader. The authenticity can take place and continue to run as the headmasters are open to new experiences, they are man of ideas and activity (action) expressed with full aesthetics and not lack of from the touch feeling. Zhou (2001, p. 688) and Woodman (1993, p. 293) state that one of the personality characteristics related to the individual's creative performance the organization is openness to experience. Be careful does not mean not brave and be a coward, Conscientiousness personality is related to the caution as the ideal person and not pragmatic, he is a fighter for the achievement (achievement striving) that does not just work and gives the minimum result as the implementation of duty, obeys to the consensus quality (dutifulness), has consistent endurance in working (self-discipline), clear consideration (Deliberation), and competence. A madrassa's leader is a person who maintains $3 \mathrm{~S}$ (smiles, greet, greeting) as a person who Agreeableness (friendly) who the depth of his heart is an altruism / trait kindness (generosity).

There is a positive and significant effect all together between the spiritual intelligence and leader's personality characteristic with the authentic leadership. The different effect level is very little showing the similarity effect between the spiritual intelligence and personality. Both cannot be separated to form the authentic leadership. Shamir and Eilam (2005, p. 395) state that the development of authentic leadership is not only formed by the leader's brain, but it is measured by real action, feedback and reflection on the 
conducted behaviour effect. The real action, feedback and reflection on the behaviour effect are strongly influenced by the spirit and personality. A leader who has a spiritual intelligence is someone who has a high awareness (self-awareness) and authentic Leadership with dimension of self-awareness will give positive effect on the performance of the people they lead. This is due to the core characteristics owned by the leaders such as self-confidence, expectation, optimism, and a tenacious attitude which will affect the work of followers and then affect on the behaviour to achieve high performance (Khan, 2010, p. 169). The research model developed by Avolio et al, (2005, p. 803) shows that the authentic leaders affect the attitudes, behaviour, and performance of followers. The headmasters' behaviour who shows selfawareness will impact on (a) the emergence of the followers' confidence, (b) the expectation to increase work productivity, (c) the optimism in achieving the planned objectives, and (d) persistence in carrying out the professional duties.

\section{CONCLUSION}

There is a positive effect between spiritual intelligence and leader's personality characteristics to the authentic leadership of madrasah aliyah's headmasters. The authentic leadership of madrasah aliyah's headmaster is affected by the spirit and personality of the leader in terms of thinking clearly (fitrab), wise in conducting duty, tolerance, openness, conscientiousness, extroversion, agreeableness and emotional stability/neuroticism. If the spiritual intelligence and leader's personality are high, so the authentic leadership of the headmasters will also get better. Thus, the headmasters of the madrasah aliyah who have spiritual intelligence and leader's personality characteristic give implications on the enhancement of headmasters' authentic leadership. The authentic ability of the headmasters can be seen from the implementation of selfawareness, processing unbiased, authentic behaviour/action and relational authenticity which comes with full confidence, expectation, optimism, and resilient by the need to improve the ability to hear, interpret, and process negative and positive information objectively before the decision is determined.

\section{BIBLIOGRAPHY}

Agustian, A. G., (2001). Kecerdasan Emosi Dan Spiritual: Rahasia Sukses Membangun Kecerdasan Emosi Dan Spiritual. Indonesia: Penerbit Arga

Amram, Y., \& Dryer, D. C., (2008). The Integrated Spiritual Intelligence Scale (ISIS): development and preliminary validation. 116th Annual Conference of the American Psychological Association, 1-46.

Ashmos, D. P., \& Duchon, D. (2000). Spirituality at work: A conceptualization and measure. Joumal of Management Inquery, 9, 134-145 
Ashton, M. C., \& Lee, K., (2007). Six independent factors of personality variation: A response to Saucier. European Journal of Personality, 16, 6375.

Ayrancy, Evren., Semercioz, Fatih. (2011). The Relationship between Spriritual Leadership and Issues of Spirituality and Religiosity: A Study of Top Turkish Managers. International Journal of Business and Management Vol.6 No. 4 April 2011. P 136-149

Avolio, B., \& Gardner, W., (2005). Authentic leadership development: Getting to the root of positive forms of leadership. Leadership Quarterly, 16(3), 315-338.

Avolio, B., Gardner, W., Walumbwa, F., \& May, D., (2004). Unlocking the mask: A look at the process by which authentic leaders impact follower attitudes and behaviors. Leadership Quarterly, 15(6), 801-823.

Azanza, G., Moriano, J. A., \& Molero, F., (2013). Authentic leadership and organizational culture as drivers of employees' job satisfaction. Revista de Psicología Del Trabajo $Y$ de Las Organizaciones, 29, 45-50. http://doi.org/10.5093/tr2013a7

Barrick, M.R. \& Mount, M.K., (1993). Effects of impression management and self-deception on the predictive validity of personality constructs. Journal of Applied Psychology, 81, 261-272.

Cooper, C, D., Scandura, T. A., \& Schriesheim, C. A., (2005). Looking forward but learning from our past: Potential challenges to developing authentic leadership theory and authentic leaders. The Leadership Quarterly, 16, 475-493.

Darvish, H., \& Rezaei, F., (2011). The Impact Of Authentic Leadership On Job Satisfaction And Team Commitment. Management \& Marketing, 6, 421-436. Retrieved from http://ezproxy.lib.ucf.edu/login?url =http://search.proquest.com/docview/899216837?accountid=10003 $\backslash$ nhttp://sfx.fcla.edu/ucf?url_ver=Z39.88-2004\&rft_val_fmt =info:ofi/fmt:kev:mtx:journal\&genre=article\&sid=ProQ:ProQ:abiglob al\&atitle $=$ THE + IMPACT $+\mathrm{OF}+$ AUTHENTIC $+\mathrm{LE}$

Delbecq, A. (1999). Christian spirituality and contemporary business leadership. Journal of Organizational Change Management, 12(4), 345-349.

Duehr, Timothy A. and Jiyce E. Bono and Judge., (2000). Five Factor Model of Personality and Transformational Leadership. Journal of Applied Psychology. 85 (5). pp:751-765

Azanza, G., Moriano, J. A., \& Molero, F., (2013). Authentic leadership and organizational culture as drivers of employees' job satisfaction. Revista de Psicología Del Trabajo Y de Las Organizaciones, 29, 45-50. http://doi.org/10.5093/tr2013a7 
Barrick, M.R. \& Mount, M.K., (1993). Effects of impression management and self-deception on the predictive validity of personality constructs. Journal of Applied Psychology, 81, 261-272.

Cooper, C, D., Scandura, T. A., \& Schriesheim, C. A., (2005). Looking forward but learning from our past: Potential challenges to developing authentic leadership theory and authentic leaders. The Leadership Quarterly, 16, 475-493.

Darvish, H., \& Rezaei, F., (2011). The Impact Of Authentic Leadership On Job Satisfaction And Team Commitment. Management \& Marketing, 6, 421-436. $\quad$ Retrieved from http:/ / ezproxy.lib.ucf.edu/login?url=http://search.proquest.com/doc view/899216837?accountid=10003 \nhttp://sfx.fcla.edu/ucf?url_ver= Z39.88-

2004\&rft_val_fmt=info:ofi $/ \mathrm{fmt}$ :kev:mtx:journal\&genre=article\&sid $=\mathrm{P}$ roQ:ProQ:abiglobal\&atitle=THE+IMPACT $+\mathrm{OF}+$ AUTHENTIC $+\mathrm{L}$ $\mathrm{E}$

Delbecq, A. (1999). Christian spirituality and contemporary business leadership. Journal of Organizational Change Management, 12(4), 345-349.

Duehr, Timothy A. and Jiyce E. Bono and Judge., (2000). Five Factor Model of Personality and Transformational Leadership. Journal of Applied Psychology. 85 (5). pp:751-765

Emuwa, A., (2013). Authentic Leadership: Commitment to Supervisor , Follower Empowerment, and Procedural Justice Climate. Emerging Leadership Journeys, 6(1), 45-65.

George, B., (2014). Authentic leadership: rediscovering the secrets to creating lasting value. Journal of the American College of Radiology: JACR, 11(5), 1-241. http://doi.org/10.1016/j.jacr.2013.11.002

Judge, T. A., Bono, J. E., Ilies, R., \& Gerhardt, M., (2002). Personality and leadership: A qualitative and quantitative review. Journal of Applied Psychology, 87, 765-780.

Kernis, M. H., (2003). Toward a conceptualization of optimal self-esteem. Psychological Inquiry, 14, 1-26.

Khan, S.N., 2010. Impact of Authentic Leaders on Organization Performance. International Journal of Business and Management, 5 (12), December 2010.

Klenke, K., (2007). Authentic Leadership: A Self, Leader, and Spiritual Identity Perspective. International Journal of Leadership Studies, 3(1), 68-97.

Kuczmarski, Susan Smith., Kuczmarski, Thomas D., (1995). Value Based Leadership. New Jersey: Prentice-Hall

Leung and Bozionelos, Sing Lim, Nikos Bozionelos., (2004). Five Factor Model Traits and the Prototypical Image of the Effective Leader in theb Confucion Culture. Employee Realtions, 26 (1/2), pp: 62-71 
Luthans, F. 2002a. The need for and meaning of positive orga- 2008 Luthans, Avey, and Patera 219 nizational behavior. Journal of Organizational Behavior, 23: 695-706

Majer, Kenneth., (2008). Values-based Leadership; A revolusionary Approach to Business Succes and Personal Prosperity. California: MajerCommunications

McAdams, D. P., \& Pals, J. L., (2006). A new Big Five: Fundamental principles for an integrative science of personality. American Psychologist, 61, 204-217.

McCrae, R. R., \& John, O. P., (1992). An introduction to the fivefactor model and its applications. Journal of Personality, 60, 175-215

Mohamed, A.A., Wisnieski, J., Askar, M., \& Syed, I., (2004). Towards a Theory of Spirituality in the Workplace. Competitiveness Review, 14(1\&2): 102-107.

Nashori, H.F., \& Mucharam, R.D., 2002. Mengembangkan kreativitas dalam Perpektif Psikologi Islami. Yogyakarta: MenaraKudus Jogja.

Ningky Munir, 2003, Spiritualitas dan Kinerja, Majalah Manajemen, Vol.124, Juli 2000

Nggermanto, A., (2002). Quantum Quotient-Kecerdasan Kuantum. Bandung: Nuansa

Noble, K.D., (2001). Riding the windhorse: Spiritual intelligence and the growth of the self. Cresskill, NJ: Hampton Press, Inc.

Opatokun, K. A., Hasim, C. N., \& Syed Hassan, S. S., (2013). Authentic Leadership In Higher Learning Institution: A Case Study Of International Islamic University Malaysia (IIUM). International Journal of Leadership Studies, 8(1), 49-66. Retrieved from http://search.ebscohost.com/login.aspx?direct $=$ true\&db=buh\&AN= 92582225\&login.asp? custid $=$ uamster\&site $=$ ehost-live

Rustiarini, N. W., (2013). Pengarub Kompleksitas Tugas, Tekanan Waktu, dan Sifat Kepribadian pada Kinerja, 17(2), 126-138. http://doi.org/10.7454/mssh.v17i2.2961

Ryan, Will., (2008). Leadership with a Moral Purpose; Turning Your School Inside Out.UK: Crown House Publishing Ltd

Shamir, B., \& Eilam, G., (2005). What's your story?Q: A life-stories approach to authentic leadership development. The Leadership Quarterly. 16(3), p. 395-417

Shaw, Eleanor ., (1999) A guide to the qualitative research process: evidence from a small firm study. International Journal, 2, 59 - 70

Sugiono., (2004). Metode Penelitian Bisnis. Bandung: Alfabeta.

Trott, David., (1996). Spiritual well-being of workers: An exploratory study of spirituality in the workplace. Dissertation Abstracts International, University of Texas: Austin, TX. 
Walumbawa, F., Avolio, B., Gardner, W., Wernsing, T., and Peterson, S. (2008). Authentic Leadership: Development and Validation of a Theory-Based Measure. Management Department Faculty Publication. paper 24.

Waworuntu, B., (2003). Determinan Kepemimpinan, 7(2), 71-81.

Woodman, R.W., Sawyer, J.E. and Griffin, R.W., (1993), Toward a theory of organizational creativity, Academy of Management Review, Vol. 18, pp.293-321.

Zhou, J., \& George, J., (2001). When job dissatisfaction leads to creativity: Encouraging the expression of voice', Academy of Management Journal, vol. 44 no. 4, pp. 682-696.

Zohar, D, Marshal, I., (2000).SQ (Spiritual Intelligence): The Ultimate Intelligence, Blomsburry Publishing, London

Zohar D., \& Marshall, I., (2007). SQ: Kecerdasan spiritual, Penerjemah: R. Astuti, A.N. Burhani, \& A.Baiquni. Bandung: PT. Mizan Media Utama. 